\title{
Development and Standardization for Preparation of Doughnut Using Millets (Jowar, Pearl, Ragi, Little, Kodo, Barnyard, Proso and Foxtail)
}

\author{
D. Satish Kumar ${ }^{1}$, G. Sudha Devi ${ }^{*}$, P. Joseph Raju ${ }^{1}$ and B. Dayakar Rao ${ }^{3}$
}

${ }^{I}$ Food Science and Technology, Satavahana University Karimnagar, Telangana, India

${ }^{2} U A S, C A E$ Raichur, Karnataka, India

${ }^{3}$ Principal Scientist IIMR-ICAR, Rajendranagar, Hyderabad, Telangana, India

*Corresponding author

\section{A B S T R A C T}

\section{Keywords}

Millets, Doughnut and Physical and proximate parameter

\section{Article Info}

Accepted:

10 December 2017

Available Online:

10 January 2018
Evaluation on the physicochemical and sensory properties of wheat flour doughnuts substituted with millet flour was investigated. Different levels of millet flour (20, 30, 40 and 50\%) and Wheat flour (80, 70, 60 and 50\%). Chemical (moisture, fat, protein and ash), physical (specific volume, weight loss, spread ratio and yield) and sensory evaluation were conducted on all samples. Proximate analyses result indicated a higher percentage of protein and fat in control doughnut compared with substituted millet flour. Doughnut yield was ranged from 29.20-34.02\%. Doughnut substituted with $40 \%$ millet flour showed the highest score in overall acceptability.

\section{Introduction}

Doughnut or donut is a type of fried dough confectionery or dessert food. The doughnut is popular in many countries and prepared in various forms as a sweet snack that can be homemade or purchased in bakeries, supermarkets, food stalls, and franchised specialty outlets. Doughnuts are usually deepfried from a flour dough, and typically either ring-shaped or without a hole, and often filled. Other types of batters can also be used, and various toppings and flavourings are used for different types, such as sugar, chocolate, or maple glazing. In addition to flour, doughnuts may also include such ingredients as water, leavening, eggs, milk, sugar, oil/shortening, natural flavours and/or artificial flavours (Hatae et al., 2003; Rehman et al., 2007). Doughnuts are made by deep-frying dough that is a mixture of flour, water, egg, oil, sugar and milk (Hatae et al., 2003). Doughnut made from non-enriched wheat flour lacks other essential nutritional composition

Millets are a group of crops grown in semiarid regions of Asian and African countries. They form a staple food for a large segment of the population, mainly those with low socioeconomic status, especially during drought or famine. They are generally included in the group of coarse cereals. Conventionally, in 
India, the term coarse cereals cover all cereals except rice and wheat. These millets are valuable in traditional food and feed. They are not usually traded in the international markets or even in local markets in many countries.

The Millet flour can then be incorporated as an ingredient for bakery products which enhances the product's nutritional value. At present, there is an increasing interest in millet products that is associated with health promoting abilities.

Hence, the study was aimed at assessing millet flour for supplement in doughnut formulations and assesses the quality of doughnut.

\section{Materials and Methods}

The millets were procured farmers and other basic ingredients namely wheat, yeast, salt and butter were procured from Hyderabad local market India.

Doughnut were prepared with varying levels of ingredients such as yeast, salt, millet flour $(20,30,40$ and $50 \%)$ and refined wheat flour $(80,70,60$, and $50 \%)$ frying time (10 $\mathrm{min})$ and temperature $\left(170^{\circ} \mathrm{C}\right)$ Figure 1 and 2.

The composition of the millet doughnut was prepared by the combination of the refined wheat flour, and other ingredients depending upon their level of acceptance from the previous study reports. All the experiments were carried out in triplicate and the average values were reported. Experimental data obtained was statistically analysed.

Chemical composition such as moisture content, protein, fat, and ash was determined according to AOAC standard method (AOAC, 2005). Moisture was determined using hot air oven at $100-105^{\circ} \mathrm{C}$ for 3 hours (AOAC, Method 945.43). Protein content (\% N x 6.25) was determined by the Kjedahl method
(AOAC, Method 950.36). Fat test was carried out based on Soxhlet Extraction Method utilizing petroleum ether $40^{\circ} \mathrm{C}-60^{\circ} \mathrm{C}$ (AOAC, Method 922.06). The ash content was measured according to dry ashing procedure (AOAC, Method 925.23). All analyses were carried out in triplicate and average value was recorded for further analysis.

The spread ratio and specific volume (Assefaw et al.,) and weight loss, yields (Arora 2016) weight loss before and after baking and volume was calculated

Sensory evaluation was used to determine millet bun was the most appropriate to way to make comparison phase of the study. The buns were analyzed by a 15 member's panelist consisting of faculty of IIMR staff. Millet bun was judged for attributes viz., colour, shape, flavour, taste, hardness and overall acceptability. Panelists worked in partitioned booths $\left(32 \pm 1^{\circ} \mathrm{C}\right)$, without air flow, free from noise and odours and under off white light in order to mask different attributes of the bun samples and therefore to prevent bias. A ninepoint hedonic scale was used to point out the differences among the bun samples.

\section{Results and Discussion}

\section{Effect of enzyme activity (Falling number) on bun flour}

A certain amount of alpha-amylase is necessary for proper baking to occur. The alpha-amylase breaks down starches to provide sugars to help fuel the fermentation process. The amount of enzyme present can have a direct bearing upon the quality of bun produced. When the alpha-amylase activity is right, a high volume bun with firm and soft texture is achieved ( $\mathrm{FN}=250$ in picture). If the activity is too high, a sticky bread crumb and low volume may result $(\mathrm{FN}=62$ in picture). If the activity is too low, a dry bread 
crumb with diminished volume may result ( $\mathrm{FN}=400$ in picture). The FN value has an inverse relationship with the alpha-amylase activity meaning the higher the alpha-amylase activity the lower the FN value, and vice-versa Table 1.

The Enzyme activity of bun flour was found in the range of 280 for all treatments and 281 for little $\left(\mathrm{d}_{1}\right.$ and $\left.\mathrm{d}_{3}\right)$ and barnyard millet flour $\left(\mathrm{d}_{3}\right)$, pearl millet $\left(\mathrm{d}_{3}\right)$ and ragi $\left(\mathrm{d}_{3}\right)$ Table 1 . It indicated that enzyme activity is normal in case of all treatment (Fig. 2).

\section{Effect of spread ratio on millet based bun}

Spread ratio is significantly influenced millet based doughnut. The spread ratios obtained for different millet based products were appreciable and were over 1.74 and as high as 2.09 .

The highest recorded jowar in $\mathrm{d} 3$ formulation fallowed by Foxtail in d4 However, the spread ratio was affected by the millet flour, increase in millet flour level decrease in the spread ratio (Fig. 3).

Fig.1 Process flow chart for preparation of doughnut

Millet, maida flour, Sugar, Salt, Yeast, Pineapple flavour and Water
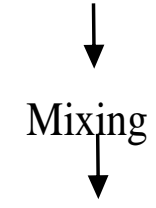

Manual kneading (about $30 \mathrm{~min}$ )

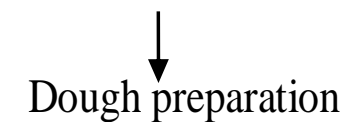<smiles></smiles><smiles>C[14CH3]</smiles><smiles>[V][Tl]</smiles>

Proofing(2 hours)

Frying $\left(170^{\circ} \mathrm{C}\right.$ for $\left.10 \mathrm{~min}\right)$
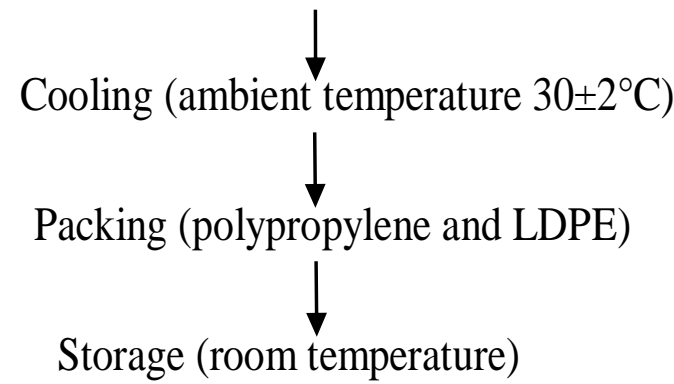
Fig.2 Millet based doughnut

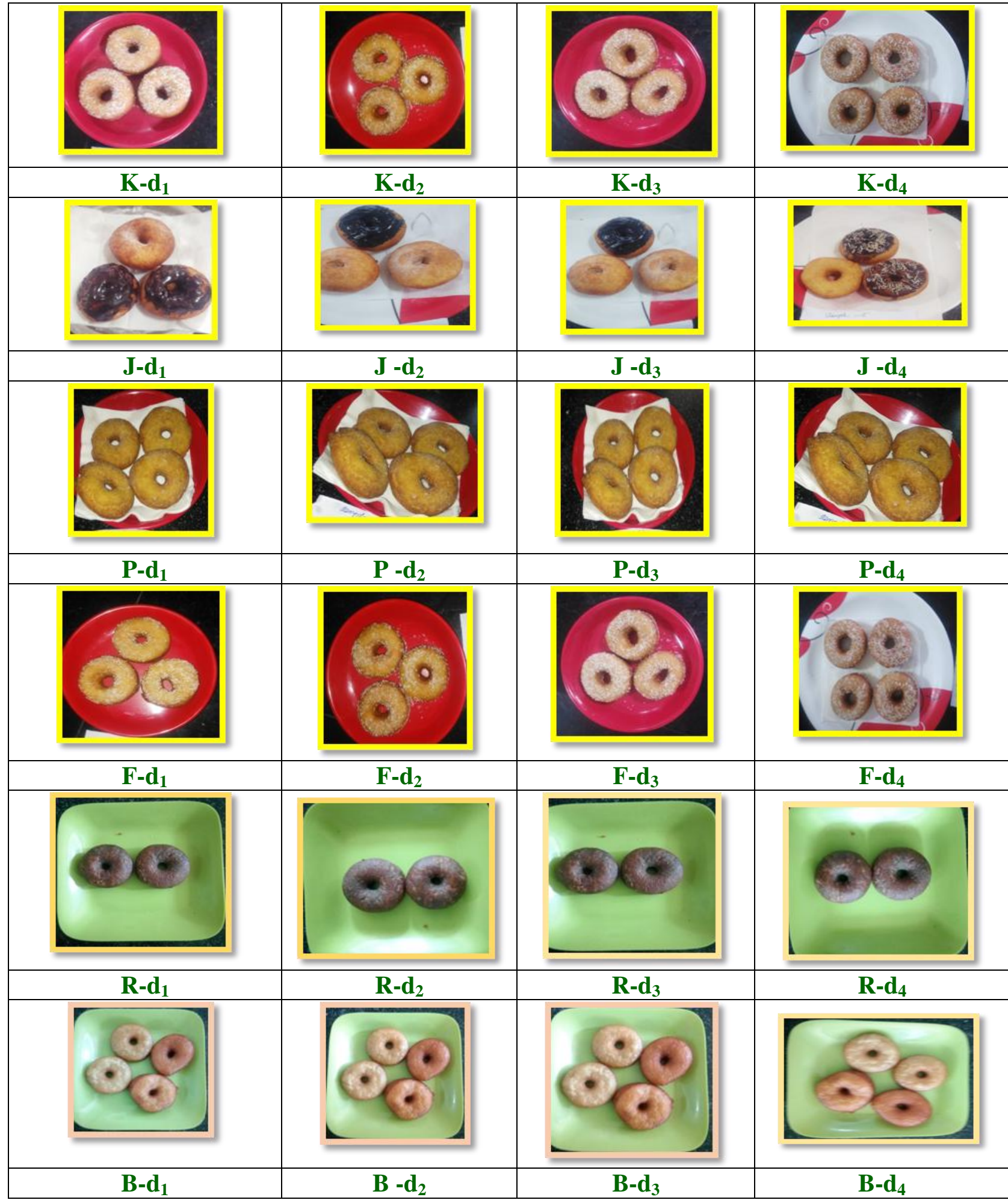

$\mathrm{d}_{1}$ - Millet flour (20\%): Maida flour (80\%); $\mathrm{d}_{2}$ - Milletflour (30\%): Maida flour (70\%); $\mathrm{d}_{3}$ - Millet flour (40\%): Maida flour (60\%); $\mathrm{d}_{4}$-Millet flour (50\%): Maida flour (50\%)

R- Ragi; L: Litte Millet; F: Foxtail Millet; K: Kodo Millet; B: Barnyard Millet; P: Proso Millet; J: Jowar; PM: Pearl Millet 
Fig.3 Frying (Doughnut) result related to falling number

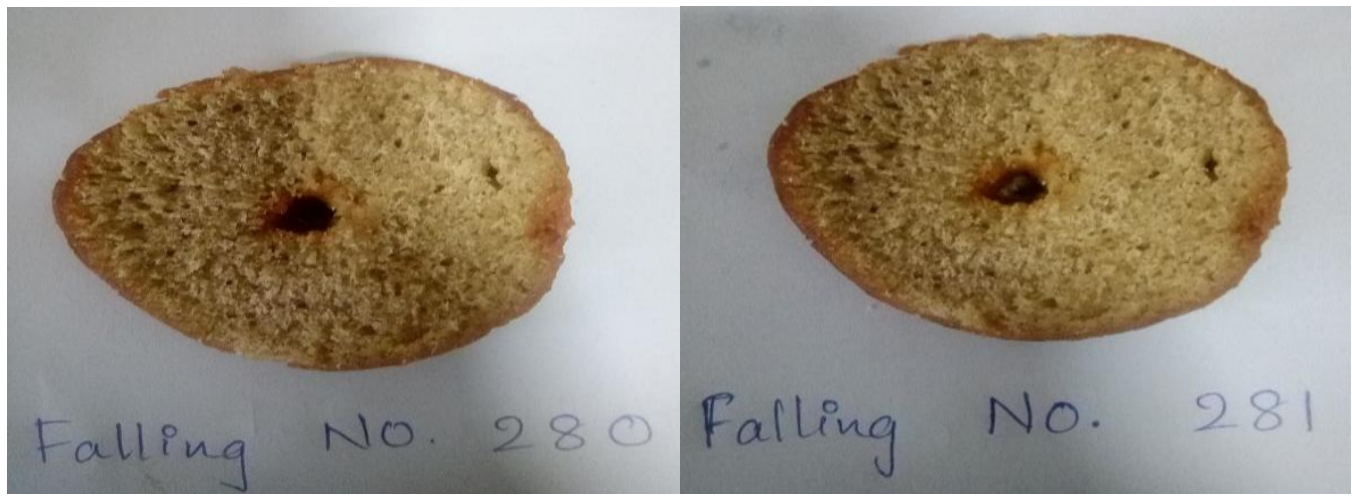

Fig.4 Effect of spread ratio on millet based doughnut

\section{Spread ratio}

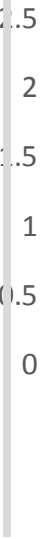

Fig.5 Effect of specific volume on millet based doughnut

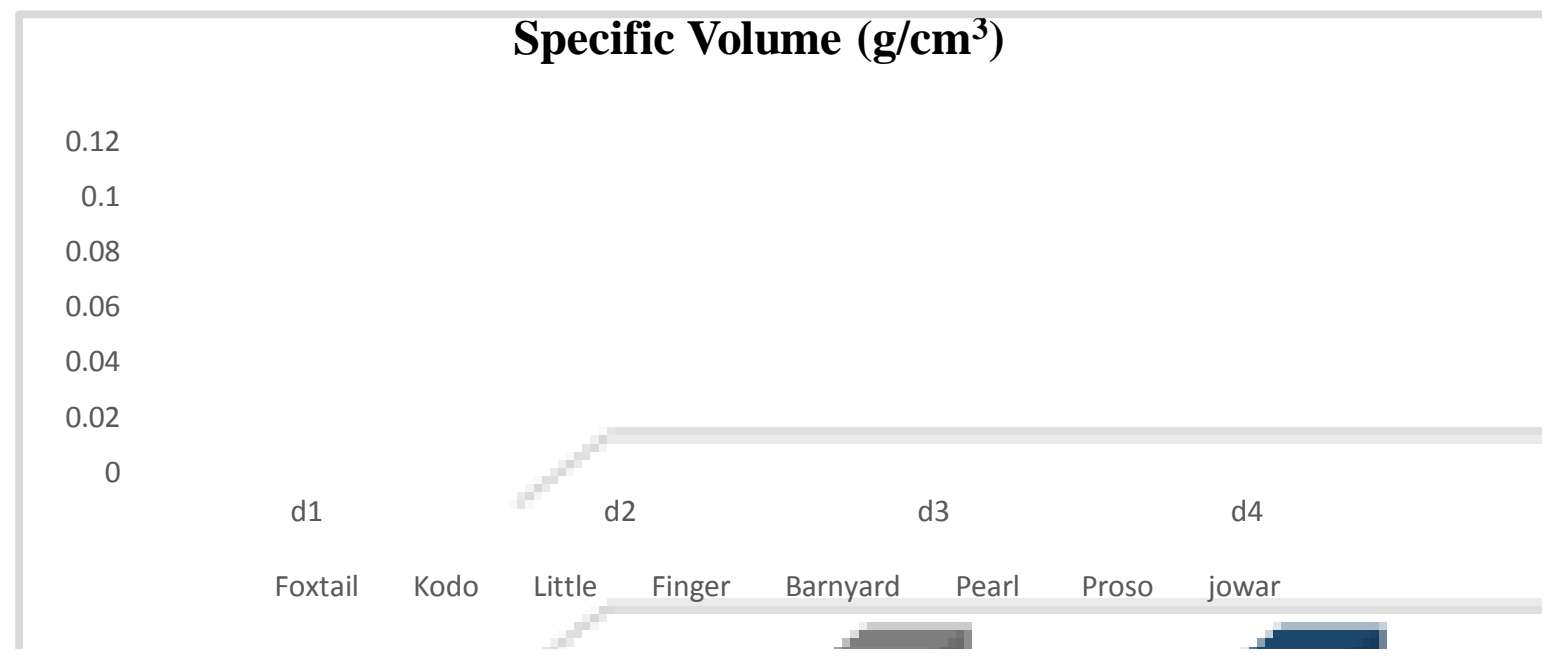


Int.J.Curr.Microbiol.App.Sci (2018) 7(1): 990-999

Fig.6 Effect of millet based doughnut on weight loss
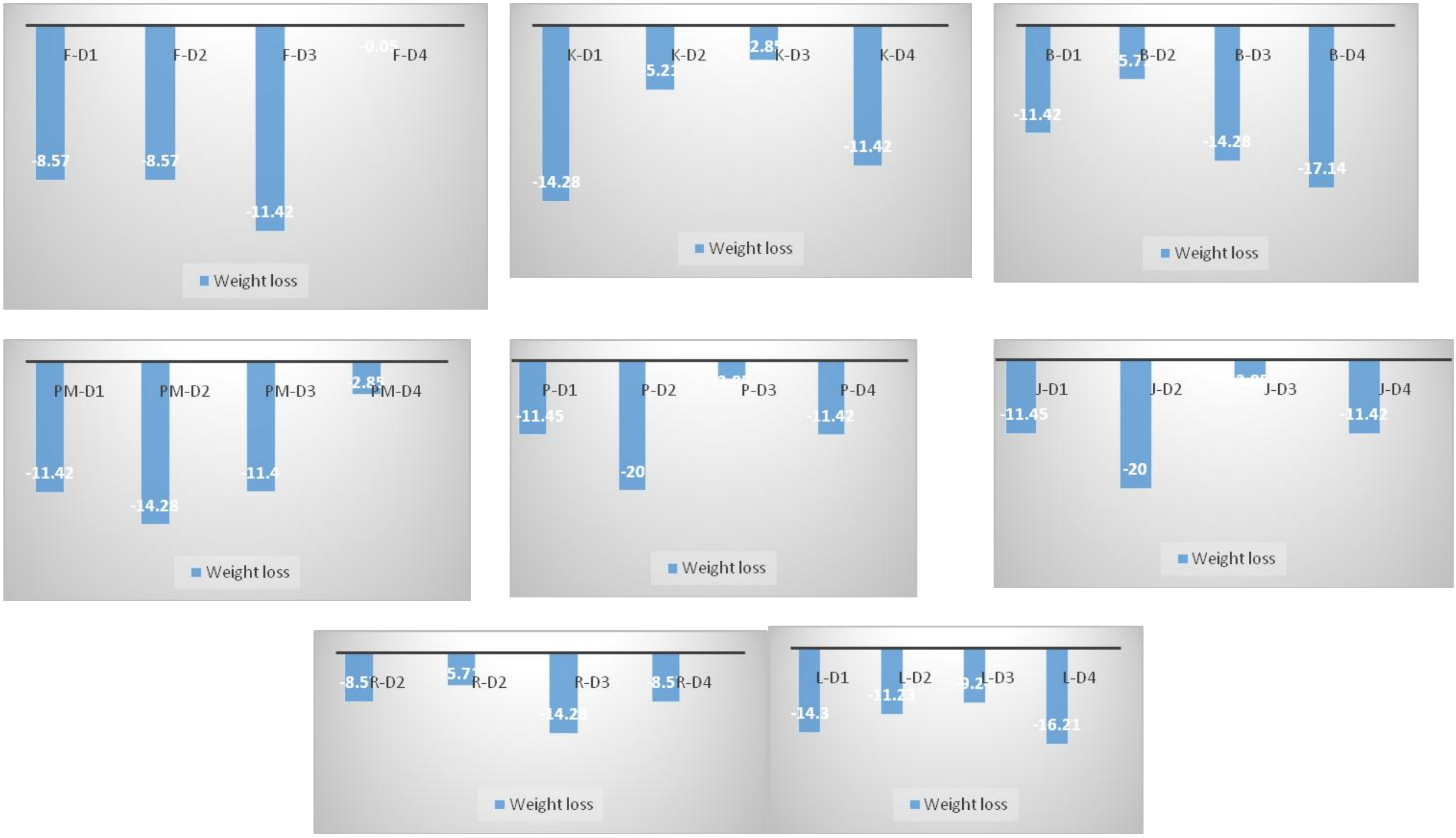
Table.1 Effect of falling number on millet based doughnut

\begin{tabular}{|c|c|c|}
\hline Treatment & Enzyme activity (FN) & Temperature \\
\hline \multicolumn{3}{|c|}{ Foxtail millet } \\
\hline F-d1 & 280 & $90^{\circ} \mathrm{C}$ \\
\hline F-d2 & 280 & $90^{\circ} \mathrm{C}$ \\
\hline F-d3 & 280 & $90^{\circ} \mathrm{C}$ \\
\hline F-d4 & 280 & $90^{\circ} \mathrm{C}$ \\
\hline \multicolumn{3}{|l|}{ Little millet } \\
\hline L-d1 & 281 & $90^{\circ} \mathrm{C}$ \\
\hline L-d2 & 280 & $90^{\circ} \mathrm{C}$ \\
\hline L-d3 & 281 & $90^{\circ} \mathrm{C}$ \\
\hline L-d4 & 280 & $90^{\circ} \mathrm{C}$ \\
\hline \multicolumn{3}{|l|}{ Kodo millet } \\
\hline K-d1 & 280 & $90^{\circ} \mathrm{C}$ \\
\hline K-d2 & 280 & $90^{\circ} \mathrm{C}$ \\
\hline K-d3 & 280 & $90^{\circ} \mathrm{C}$ \\
\hline K-d4 & 280 & $90^{\circ} \mathrm{C}$ \\
\hline \multicolumn{3}{|c|}{ Barnyard millet } \\
\hline B-d1 & 280 & $90^{\circ} \mathrm{C}$ \\
\hline B-d2 & 281 & $90^{\circ} \mathrm{C}$ \\
\hline B-d3 & 280 & $90^{\circ} \mathrm{C}$ \\
\hline B-d4 & 280 & $90^{\circ} \mathrm{C}$ \\
\hline \multicolumn{3}{|l|}{ Proso millet } \\
\hline P-d1 & 280 & $90^{\circ} \mathrm{C}$ \\
\hline P-d2 & 280 & $90^{\circ} \mathrm{C}$ \\
\hline P-d3 & 280 & $90^{\circ} \mathrm{C}$ \\
\hline P-d4 & 280 & $90^{\circ} \mathrm{C}$ \\
\hline Jowar & 280 & $90^{\circ} \mathrm{C}$ \\
\hline J-d1 & 280 & $90^{\circ} \mathrm{C}$ \\
\hline $\mathrm{J}-\mathrm{d} 2$ & 280 & $90^{\circ} \mathrm{C}$ \\
\hline $\mathrm{J}-\mathrm{d} 3$ & 280 & $90^{\circ} \mathrm{C}$ \\
\hline $\mathrm{J}-\mathrm{d} 44$ & 280 & $90^{\circ} \mathrm{C}$ \\
\hline \multicolumn{3}{|l|}{ Pear Millet } \\
\hline PM-d1 & 280 & $90^{\circ} \mathrm{C}$ \\
\hline PM-d2 & 280 & $90^{\circ} \mathrm{C}$ \\
\hline PM-d3 & 281 & $90^{\circ} \mathrm{C}$ \\
\hline PM-d4 & 280 & $90^{\circ} \mathrm{C}$ \\
\hline \multicolumn{3}{|c|}{ Ragi } \\
\hline R-d1 & 280 & $90^{\circ} \mathrm{C}$ \\
\hline R-d2 & 280 & $90^{\circ} \mathrm{C}$ \\
\hline R-d3 & 281 & $90^{\circ} \mathrm{C}$ \\
\hline R-d4 & 280 & $90^{\circ} \mathrm{C}$ \\
\hline
\end{tabular}


Table.2 Effect on nutritional composition of doughnut

\begin{tabular}{|c|c|c|c|c|}
\hline Formulation & Moisture (\%) & Protein (\%) & Fat $(\%)$ & Ash (\%) \\
\hline Control & 5.30 & 6.00 & 18.50 & 0.98 \\
\hline$B-d_{3}$ & 6.26 & 11.30 & 12.80 & 1.00 \\
\hline $\mathbf{F}-\mathbf{d}_{\mathbf{3}}$ & 9.00 & 11.15 & 1.70 & 1.04 \\
\hline$L-d_{3}$ & 5.23 & 10.20 & 14.3 & 1.00 \\
\hline K- $\mathbf{d}_{3}$ & 5.43 & 11.80 & 1.70 & 0.99 \\
\hline$R-d_{3}$ & 6.51 & 16.80 & 3.36 & 0.88 \\
\hline PM-d $\mathbf{3}_{3}$ & 6.39 & 9.10 & 7.83 & 0.97 \\
\hline$P-d_{3}$ & 6.96 & 9.40 & 9.30 & 0.98 \\
\hline$J-d_{3}$ & 7.06 & 11.60 & 8.09 & 0.95 \\
\hline
\end{tabular}

Fig.7 Effect of millet based doughnut on yield

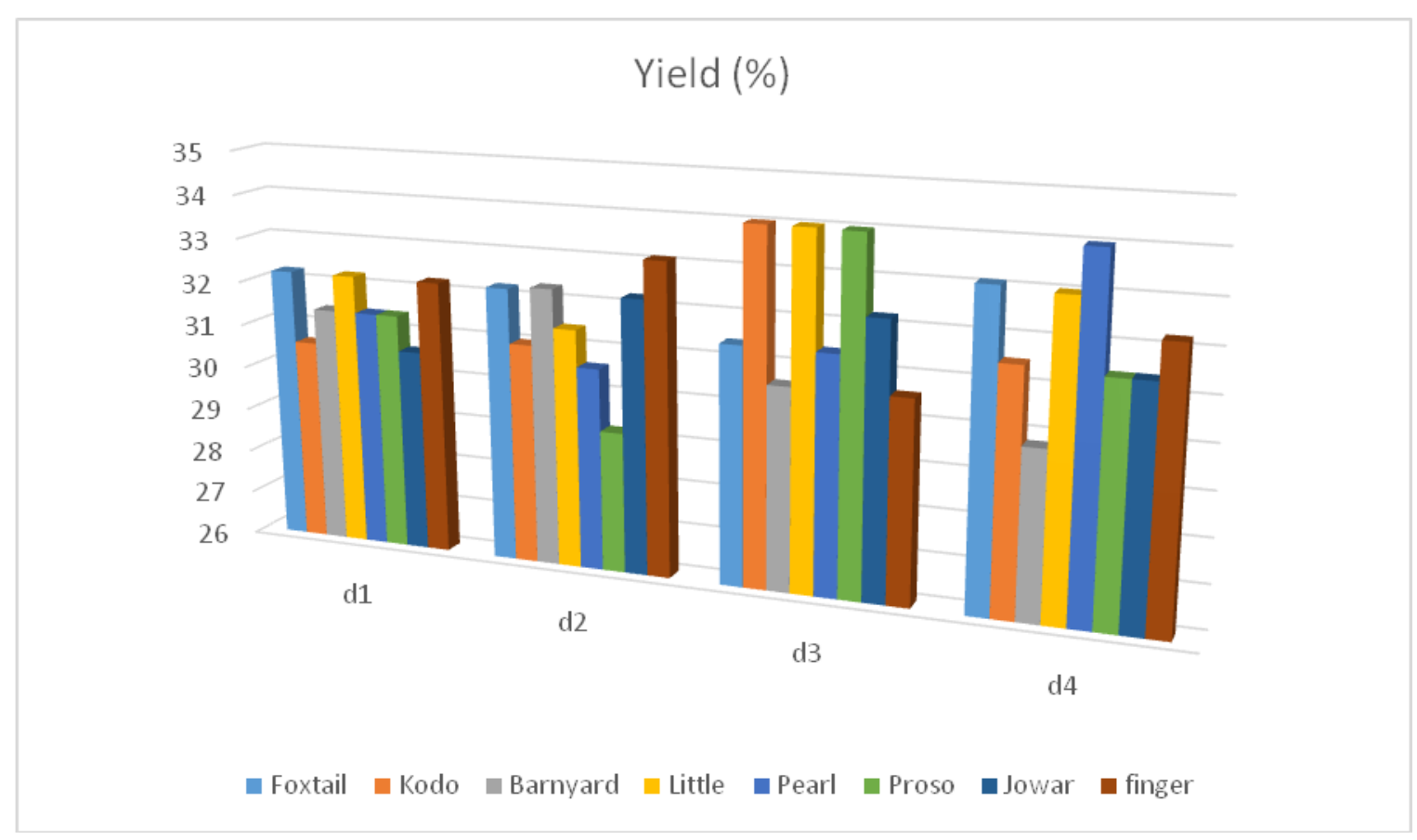

Effect of specific volume $\left(\mathrm{g} / \mathrm{cm}^{3}\right)$ on millet based doughnut

Specific volume is significantly influenced millet based bun.

The specific volume obtained for different millet based products were ranged from $0.110-0.086 \mathrm{~cm}^{3} / \mathrm{g}$, the specific volume. The highest recorded was jowar in $\mathrm{d}_{2}$ formulation fallowed by little $\mathrm{d}_{3}$ formulation (Fig. 4).
Effect of doughnut weight loss $(\%)$ on millet based doughnut

Weight loss is the removal of moisture during frying process. It was found that with the increase of substitution percentage, the weight loss after frying also increased. This may be due to the high oil holding capacity of the composite flour constituent. It was ranged $2.85 \%$ to $-14.28 \%$. Similar result was found in Raihan et al., 2016 (Fig. 5). 
Effect of millet based doughnut on yield (\%)

Yield in baking product is the percentage of the product obtained after baking. It was found that $29.20 \%$ to $34.02 \%$ (Fig. 6).

The highest was recorded in case of kodo, little, pearl millet and lowest was recorded in case of proso. This happened due to less water loss during frying process. Similar result was found in Raihan et al., (2016).

\section{Organoleptic quality}

The organoleptic quality which included colour, appearance, texture, flavor, taste and overall acceptability of millets based doughnut products prepared using eight millets

The mean sensory scores of millet doughnut products for overall acceptability revealed that there was no difference among the formulations and the control whole-maida flour doughnut. The highest score was recorded for $\mathrm{f}_{4}(40 \%$ millet flour) formulation in all millets and it is acceptable

\section{Effect on nutritional composition of Doughnut}

\section{Moisture, protein, fat and ash}

The effects of moisture content of millet based bun products. In case of all best treatment it ranges from $9.00 \%$ to $5.23 \%$. The highest was found in foxtail millet doughnut and least was recorded in little millet doughnut (Table 2).

The effects of protein content of millet based bun products. In case of all best treatment it ranges from $11.80 \%$ to $6.00 \%$. The highest was found in kodo millet doughnut and least was recorded in control due to refined maida flour. The effects of fat content of millet based bun products. In case of all best treatment it ranges from $18.50 \%$ to $1.70 \%$. The highest was found in control and least was recorded in foxtail millet doughnut.

The effects of ash content of millet based bun products. In case of all best treatment it ranges from $1.04 \%$ to $0.88 \%$.

The maximum scores for colour, texture, taste, hardness were given to doughnut made by $40 \%$ substitution, overall bun prepared from $40 \%$ substitution was having maximum acceptability. The enzyme activity of doughnut flour was found in the range of 280281 in all the treatment, it indicated that enzymes activity is normal in case of all the treatment. The spread ratio was having maximum in foxtail $\left(\mathrm{d}_{4}\right)$, Kodo $\left(\mathrm{d}_{3}\right)$ Finger and barnyard $\left(\mathrm{d}_{1}\right)$ formulation and specific volume was found good in all the treatment. The weight loss was highest in (40\% Millet flour) formulation. The highest yield was recorded (40\% millet flour) formulation. Proximate analyses result indicated a higher percentage of protein and fat in control doughnut compared with substituted millet flour.

\section{References}

AOAC, 2005. Official methods of analysis (16th Edition). Association of Official Analytical Chemists, Washington, DC.

Arora, A and Saini, S.C., 2016. Development of bun from wheat flour fortified with de-oiled maize germ, Cogent Food and Agriculture, 21183252.

Assefaw, E and Fu, B.X., Development and quality Evaluation of Navy Bean Flour steamed Bread.

Asta, C. D., Cirlini, M., Morini, E., Rinaldi, M., Ganino, T. and Chiavaro, E., 2013. Effect of chestnut flour supplementation on physico-chemical properties and 
volatiles in bread baking. LWT- Food Sci. Technol., 53(1): 233-239.

Hatae, K., Miyamoto, T., Shimada, Y., Munekata, Y., Sawa, K., Hasegawa, K. and Kasai, M. 2003. Effect of the type of frying oil on the consumer preference for doughnut. Journal of Food Science, 68: 1038-1042

Raihan, M and Saini, C.S, 2016. Development of multigrain bun from oats, sorghum, amaranth and wheat, 5(2): 50-56.

Rehman, S., Paterson, A., Hussain, S., Murtaza, M.A. and Mehmood, S. 2007. Influence of partial substitution of wheat flour with vetch (Lathyrus sativus L) flour on quality characteristics of doughnuts. Lebensmittel-Wissenchaft und-Technologie, 40(1): 73-82.

\section{How to cite this article:}

Satish Kumar, D., G. Sudha Devi, P. Joseph Raju and Dayakar Rao, B. 2018. Development and Standardization for Preparation of Doughnut Using Millets (Jowar, Pearl, Ragi, Little, Kodo, Barnyard, Proso and Foxtail). Int.J.Curr.Microbiol.App.Sci. 7(01): 990-999. doi: https://doi.org/10.20546/ijcmas.2018.701.119 